\title{
Floor of Mouth Mucoepidermoid
}

\section{Carcinoma}

National Cancer Institute

\section{Source}

National Cancer Institute. Floor of Mouth Mucoepidermoid Carcinoma. NCI Thesaurus.

Code C8178.

A mucoepidermoid carcinoma of the oral cavity that arises from the floor of the mouth. 